\title{
PELUANG PEMANFAATAN PEMBELAJARAN BERORIENTASI TEKNOLOGI INFORMASI DI LINGKUP MADRASAH (MEMPERSIAPKAN MADRASAH BERWAWASAN GLOBAL)
}

\author{
Maesaroh Lubis \\ Universitas Ibn Khaldun Bogor; Maylub13@gmail.com
}

Diterima: 3 September 2016. Disetujui: 25 Oktober 2016. Dipublikasikan: Desember 2016

\begin{abstract}
Abstrak
The rapid development of information technology and the changing social and political situation around the world brings new challenges to madrasah. Madrasahs are challenged to transform themselves into institutions that are able to adapt to changing society. That means the madrasah must be able to adapt to the globalization process. Therefore, madrasah should be able to identify challenges and formulate strategies. The most important thing to note is that the process of change is not aimed at the institution itself, but rather to help students as the next generation of nations to embrace a different world, a globalized world characterized by constant technological change and different social lives.
\end{abstract}

\begin{abstract}
Abstrak
Pesatnya perkembangan teknologi informasi dan perubahan situasi sosial dan politik di seluruh dunia membawa tantangan baru untuk madrasah. Madrasah ditantang untuk mengubah dirinya menjadi lembaga yang mampu beradapt asi dengan perubahan masyarakat. Itu artinya madrasah harus mampu beradaptasi dengan proses globalisasi. Oleh karena itu, madrasah harus mampu mengidentifikasi tantangan dan memformulasikan strategi. Yang paling penting untuk dicatat adalah bahwa proses perubahan itu tidak ditujukan pada lembaga itu sendiri, melainkan untuk membantu siswa sebagai generasi penerus bangsa untuk merangkul dunia yang berbeda, dunia yang mengglobal yang ditandai dengan perubahan teknologi yang terus terjadi dan kehidupan sosial yang berbeda.
\end{abstract}

Kata kunci: Madrasah,Pembelajaran,Teknologi Informasi, Globalisasi

C 2016 URPI, FTK IAIN Raden Intan Lampung

\section{PENDAHULUAN}

Madrasah sebagai salah satu benteng pertahanan dalam pembinaan umat Islam diharapkan dapat menemukan momentum untuk menjadikan diri sebagai lembaga pembinaan umat yang layak diperhitungkan dengan fokus pada optimalisasi, efisiensi dan efektivitas pembinaan agar menghasilkan produk yang bermutu dan melahirkan kaderkader tangguh tanpa harus mengabaikan ciri khas sebagai lembaga pendidikan Islam.

Proses bagaimana mengelola output pendidikan madrasah dimaksud sangat dipengaruhi oleh tumbuh dan kembangnya inisiatif para pelaksana pendidikan dalam menyiasati kurikulum (Maksum, 2006). Kata "proses" memberikan ilustrasi tentang hal-hal yang menyangkut langkah-langkah/ sistematika/ urutan/ jalannya suatu kegiatan yang disebut sebagai sebuah kegiatan pembelajaran dan secara metodologis berakar dari pihak pendidik yaitu guru (Subhan, 2012).

Keprihatinan terhadap kualitas pendidikan di lembaga pendidikan Islam sudah muncul sejak lama. Pendidikan di madrasah selama ini seakan-akan tersisih dari mainstream pendidikan nasional, sekalipun berkenaan dengan pendidikan anak bangsa, posisi madrasah dalam sistem pendidikan nasional juga relatif menghadapi berbagai kendala dalam hal 
mutu, manajemen, dan kurikulum. (Tilaar, 2000)

Oleh karena itu, pembenahan lembaga pendidikan Islam harus difokuskan kepada sistem organisasi, strategi, dan metode kerja agar dapat memenuhi tuntutan masyarakat modern. Madrasah dituntut mampu menawarkan pemahaman Islam yang modern agar dapat menyikapi perkembangan kehidupan manusia. Kontekstualisasi ini tidak lain adalah usaha menemukan titik temu antara hakikat Islam dan semangat zaman. Disinilah letak keuniversalan Islam, yaitu ketika mampu mampu menampilkan ide dan lembaga yang modern serta menawarkan etika modernisasi.

Umumnya memang masih banyak kalangan yang berpandangan bahwa madrasah sebagai lembaga pendidikan Islam masih menghadapi hambatan yang besar seperti sifatnya yang tertutup dan sangat ortodoks dan belum terbuka terhadap kemajuan ilmu dan teknologi, padahal perubahan yang besar sedang terjadi di sekitar pendidikan Islam yang mengakibatkan efek globalisasi tidak dapat diabaikan, karenanya yang perlu dilakukan lembaga pendidikan Islam adalah menghadapinya dengan cara mengeliminir atau mensiasati dampak negatif yang ditimbulkan sehingga dari madarasah akan lahir generasi Indonesia yang unggul dan berdaya saing sebagaimana diamanatkan melalui Undang-Undang namun tetap berwawasan keislaman.

\section{PEMBAHASAN}

\section{A. Madrasah dan Tantangan Globalisasi}

Sebagai lembaga pendidikan yang bercirikan nilai-nilai Islam, madrasah saat ini memasuki tahapan baru dalam perkembangannya yaitu harus beradaptasi dengan globalisasi. Dalam perspektif ini, globalisasi dimaknai sebagai penguasaan Ilmu Pengetahuan dan Teknologi, sedangkan penguasaan ilmu pengetahuan dan teknologi sangat terkait dengan kualitas Sumber Daya Manusia (Yunus, 1996). Oleh karena itu, madrasah diharapkan mampu menghasilkan lulusan yang mampu memainkan peran penting di semua sektor kehidupan bangsa, baik itu sektor agama, sosial, ekonomi, politik, ilmu pengetahuan dan teknologi.

Ini adalah masalah penting untuk didiskusikan mengingat kondisi madrasah di Indonesia saat ini. Setidaknya terdapat dua masalah utama yang dihadapi madrasah di seluruh Indonesia terkait dengan globalisasi.Yang pertama adalah kesadaran akan pentingnya teknologi, karena teknologi memainkan peran penting di era global, akses terhadap informasi dan teknologi komunikasi menjadi sangat vital bagi kesuksesan sebuah lembaga. Yang kedua adalah adaptasi terhadap budaya yang berbedabeda, teknologi informasi tidak datang bebas nilai, namun datang bersama dengan beragam budaya asing yang adakalanya untuk memperkaya budaya yang ada namun tak jarang pula mengancam nilai-nilai yang berlaku. Selain itu, teknologi juga menghasilkan budaya sebagai dampak dari penggunaan teknologi itu sendiri.

Dengan memahami hal tersebut, madrasah ditantang untuk beradaptasi dengan perkembangan teknologi informasi dan implikasinya. Hal ini berarti madrasah dituntut untuk mengubah dirinya menjadi lembaga pendidikan yang menghargai teknologi informasi dan komunikasi sebagai media dan sebagai sumber daya untuk pendidikan. Ini merupakan satu-satunya cara untuk membuat madrasah mampu beradaptasi dengan masyarakat yang berubah.

Di beberapa lembaga pendidikan saat ini tak terkecuali madrasah, penggunaan komputer sebagai manifestasi dari teknologi telah menjadi bagian integral kurikulum, baik di tingkat menengah pertama maupun menengah keatas, teknologi informasi telah menjadi 
cakupan kurikulum sekolah. Dengan mengintegrasikan teknologi informasi dalam kurikulum persekolahan diharapkan dapat meningkatkan kapabilitas dan produktifitas pembelajaran. Sebagai jantung dari program sekolah, kurikulum madrasah perlu dirancang bagaimana caranya memfasilitasi proses pembelajaran sehingga secara sosial dan kultural peserta didik madrasah siap berhadapan dengan dunia global.

Meskipun perkembangan teknologi membawa akibat timbulnya permasalahan dalam bidang pendidikan, akan tetapi kehadiran teknologi dapat membantu memecahkan permasalahan pendidikan apabila teknologi informasi itu dikembangkan atau diadopsi dan dikemas sesuai dengan prinsip-prinsip teknologi pembelajaran terutama yang mengacu kepada nilai-nilai Islam, karena ada sebagian pendapat orang awam, kehadiran teknologi informasi justru merusak sendi-sendi agama bukan membantu membangun dan menginternalisasikan ajaran. Hal ini bisa benar apabila teknologi informasi tidak dimanfaatkan untuk kegiatan produktif dan berbagai aktivitas yang kontraproduktif. Padahal Penggunaan teknologi yang sesuai memungkinkan peserta didik meningkatkan pengetahuan dan keterampilan dan bahkan sikap terhadap lingkungan belajar. Dengan demikian teknolgi bukan sekedar alat tetapi juga sebagai sarana untuk membangun pengetahuan, keterampilan dan sikap peseta didik. Teknologi menjadi sarana konstruktif dan fasilitas yang diperlukan untuk mengembangkan cara berfikir kritis dan dapat diaplikasikan terhadap kawasan bidang studi.

Akan tetapi masalah pemanfaatan teknologi dalam proses pembelajaran sebagai bagian dari trend globalisasi ini jika dikaitkan dengan kualitas lembaga yang bernama madrasah ini menurut banyak pengamat cukup memprihatinkan. Kalau banyak orang mengatakan bahwa bangsa Indonesia belum siap untuk memasuki era globalisasi, maka lulusan madrasah dikhawatirkan lebih tidak siap lagi.

karenanya, terkait dengan era globalisasi ini, maka madrasah harus juga menyiapkan anak didiknya untuk siap bersaing di dunia global, hal ini dimaksudkan agar lulusan madrasah tidak akan mengalami marginalisasi, dan lagilagi yang menjadi ujung tombak dari proses "melahirkan" generasi yang siap mengahadapi tantangan masa depan terletak di tangan para pendidik, dalam hal ini guru, guru madrasah yang menguasai posisi teknologi terhadap kualitas proses pembelajaran yang berdaya saing.

Seluruh warga belajar di madrasah harus memahami dan siap berhadapan dengan tantangan untuk beradaptasi dengan perkembangan teknologi informasi dan implikasinya.Itu artinya, madrasah harus mampu mengubah dirinya menjadi lembaga pendidikan yang menghargai teknologi informasi dan komunikasi sebagai media dan sumber daya untuk pendidikan.

\section{B. Peluang Pemanfaatan Teknologi Informasi di Madrasah}

Perkembangan ilmu pengetahuan dan teknologi turut merubah paradigma pembangunan pendidikan dan berbagai sektor kehidupan. Perubahan paradigma ini telah mengubah pula seluruh aktivitas kehidupan termasuk dalam kegiatan pembelajaran. Salah satu perkembangan teknologi yang sangat memengaruhi aktivitas kehidupan adalah hadirnya teknologi informasi yang begitu canggih yang mengarah kepada komunikasi yang lebih komprehensif. Era teknologi informasi ini dapat dibuktikan dengan kenyataan bahwa seluruh informasi dapat di kemas sperti media cetak, suara atau bunyi, dan gambar dalam bentuk digital. 
Perkembangan teknologi informasi yang sangat pesat telah juga memengaruhi berbagai aspek kehidupan manusia termasuk bidang pendidikan. Perkembangan teknologi pendidikan tidak dapat dipisahkan dari perubahan yang terjadi di bidang teknologi dan di bidang pendidikan. Teknologi informasi sekarang ini telah mengalami perkembangan yang luar biasa seperti portofolio elektronik, game dan simulasi komputer, buku digital (e-book), teknologi nirkabel (wireless) dan mobile computing (Purwanto, 2005).

Implementasi teknologi informasi di tingkat sekolah/madrasah bukanlah tanpa tantangan dan hambatan. Pertama, dana seringkali menjadi hambatan dalam penggunaan teknologi informasi karena membutuhkan investasi yang sangat besar. Perencanaan arsitektur teknologi informasi yang baik dengan mempertimbangakan kapasitas pendanaan menjadi sangat diperlukan. Kerjasama dengan fihak lain melalui outsourcing juga merupakan alternatif yang perlu dipertimbangkan. Pimpinan sekolah dalam konteks ini harus menyadari bahwa fokus penggunaan teknologi informasi dalam tahapan ini tidak untuk efisiensi tetapi untuk efektivitas. (Earl \& Feeny, 2000)

Teknologi, dalam hal ini teknologi elektronik, memiliki peran sangat penting dalam memberikan kemudahan belajar dalam latar sekolah. Means dan Olson mengemukakakn bahwa teknologi :1) Memudahkan guru menyajikan tugastugas dan bahan yang lebih kompleks, 2) Mensupport guru menjadi coaches bukannya dispenser pengetahuan, 3) Menjadi sarana yang nyaman bagi guru dalam melaksanakan kurikulum, antara lain terkait di kawasan strategi (Metode, Media), 4) Memberikan motivasi kepada peserta didik untuk belajar lebih giat dan cermat melakukan aktivitas pembelajaran, dan 5) Menambah nilai plus (contoh; nilai kultural) tugas-tugas sekolah (Means \& Olson, 1993).
Pemanfaatan teknologi informasi di bidang pendidikan contohnya adalah $e$ learning, e-book, e-education, dan juga $e$ library. Penggunaan teknologi informasi dalam dunia pendidikan terus berkembang seiring kemajuan teknologi dan infrastruktur. Penerapan teknologiteknologi ini sering dijumpai dalam pembelajaran-pembelajaran para siswa dengan adanya kombinasi antara metode pembelajaran dengan audio-data, videodata, audio-video, dan juga internet.

Penggunaan komputer di sekolah memberikan perbedaan pemahaman diantara peserta didik tentang pengalaman belajar yang dialaminya. Peserta didik dapat belajar baik secara individual dan kolaboratif dalam suatu kelompok untuk menyelesaikan tugas belajar mereka. Dengan demikian teknologi dapat mempermudah peserta didik melakukan aktivitasnya di dalam kelas. Penggunaan teknologi memungkinkan peserta didik meningkatkan pengetahuan dan keterampilan dan bahkan sikap terhadap lingkungan belajar. Dengan demikian teknolgi bukan sekedar alat tetapi juga sebagai sarana untuk membangun pengetahuan, keterampilan dan sikap pebelajar. Teknologi menjadi sarana konstruktif dan fasilitas yang diperlukan untuk mengembangkan cara berfikir kritis dan dapat diaplikasikan terhadap kawasan bidang studi. Teknologi sebagai peralatan misalnya dapat dipakai untuk menyimpan data base, jaringan komunikasi sistem kepakaran, konfrensi melalui komputer interaktif, multimedia hypermedia, komunikasi teknologi jarak jauh (teletecom) sistem jaringan dan sebagainya. Jonassen lebih jauh mengemukakan secara singkat penggunaan teknolgi sebagai sarana yang dapat mendukung aktivitas-aktivitas yang banyak melibatkan peserta didik dalam belajar bermakna. Tuntutan semacam ini berkenaan dengan bagaimana keefektifan teknologi tersebut dalam meningkatkan kinerja peserta didik. (Jonassen, Camlell, \& Davidson, 1993). 
Knapp \& Glenn mengemukakan mengapa peserta didik lebih menyukai penggunaan teknologi (komputer) dan lebih senang mengikuti pembelajaran yang menggunakan komputer (Knapp \& Glenn, 1996). Program perangkat lunak komputer yang efektif secara aktif melibatkan peserta didik dan dapat mengendalikan secara bebas. Dengan menggabungkan teknologi komputer kedalam pembelajaran dapat meningkatkan sikap positif peserta didik terhadap sekolah, pelajaran dan belajar secara umum, mengingat sikap terhadap belajar meningkat, harga diri dan keinginan untuk berkembang juga meningkat. Cotton menyimpulkan hasil penelitian tentang pembelajaran berbantuan komputer jika dikaitkan dengan komputer sebagai bagian dari pembelajaran (Kozma, R, 1991). Penelitian tersebut membuktikan bahwa kombinasi penyajian media (video) mampu menghasilkan kemampuan mengingat informasi lebih baik dari pada hanya melihat gambar, membaca atau mendengarkan. (Kozma, R, 1991). Di samping itu, video gerak ini memberikan kesan mendalam bagi pemirsanya dan sekaligus memberikan pengaruh pada kawasan pengetahuan, sikap dan keterampilan.

Teknologi informasi telah membuka mata dunia, disadari betul bahwa perkembangan teknologi, telah mengubah pola interaksi masyarakat, yaitu interaksi bisnis, ekonomi, sosial, budaya dan bahkan pendidikan. Dalam kegiatan pembelajaran teknologi menunjang efektivitas dan efisiensi kegiatan pembelajaran, terutama peranannya sebagai sumber belajar, sarana komunikasi, publikasi serta sarana untuk mendapatkan berbagai informasi atau bahan belajar yang dibutuhkan, sebagaimana dikemukakan Indrajit tentang fungsi ideal teknologi informasi dalam bidang pendidikan semestinya memenuhi kriteria-kriteria seperti : 1) 4 . sebagai gudang ilmu; 2) sebagai alat bantu pembelajaran; 3) sebagai fasilitas pendidikan; 4) sebagai standar kompetensi; 5) sebagai penunjang administrasi; 6) sebagai alat bantu manajemen sekolah; dan 7) sebagai infrastruktur pendidikan (Indrajit, 2004).

Karena itu, para pemangku kebijakan di madrasah perlu mengambil sikap adaptif dan secara sekaligus defensif terhadap teknologi dan semua hal yang berbau scientific agar pendidikan Islam (madrasah dalam hal ini) dapat menempatkan diri di tengah-tengah dunia global. Pentingnya teknologi informasi dalam pendidikan dan perlunya rumusan yang jelas tentang pemanfaatannya dalam proses pembelajaran agar betul-betul memberi peran dalam pencapaian tujuan pendidikan terutama para pemegang kebijakan

Para pemangku kebijakan madrasah harus memikirkan bagaimana aplikasi pengembangan sistem dan model pembelajaran berbasis teknologi informasi dilakukan, misalnya dengan melakukan pengkajian atas seluruh unsur dan aspek pemanfaatan teknologi informasi untuk pembelajaran sehingga bisa didapatkan pegangan sebagai bahan pengambilan keputusan dalam pengembangan sistem pembelajaran berbasis teknologi informasi. Bahwa pengembangan sistem dan model pembelajaran berbasis teknologi informasi baik bersifat off line (multimedia) maupun yang bersifat on line (internet) diperlukan pertimbangan dan penilaian atas beberapa hal sebagai berikut :

1. Keuntungan, sejauhmana sistem akan memberikan keuntungan bagi institusi, staf pengajar, pengelola dan terutama keuntungan yang akan diperoleh peserta didik dalam meningkatkan kualitas pembelajaran.

2. Biaya pengembangan infrastruktur serta pengadaan peralatan .

3. Biaya operasional dan perawatan.

Sumber daya manusia. 
Namun sayang sekali ternyata masih sedikit sekali sikap madrasah yang merespon positif dalam menghadapi tantangan dunia global dalam proses pembelajaran, padahal jika ditinjau dari peranan pendidikan, maka madrasah harus berorientasi ke depan, atau berada pada level menyongsong terjadinya globalisasi. Madrasah harus berupaya mempersiapkan program pengembangan teknologi informasi secara menyeluruh. Melalui perencanaan yang matang, madrasah bisa mengembangankan teknologi informasi secara bertahap agar tidak tertinggal dari sekolah lain.

Sebagaimana telah dipaparkan sebelumnya bahwa teknologi informasi hanya merupakan salah satu solusi yang harus diikuti dengan solusi pada bidang yang lain yakni sumber daya manusia, proses dan organisasi (manajemen dan struktur).

Berbicara mengenai komponen sub sistem pendidikan (pembelajaran dalam makna yang terbatas), maka komponen guru (SDM) merupakan bagian terpenting dalam proses pembelajaran di sekolah. Guru merupakan ujung tombak pendidikan. Keberadaan guru menjadi aspek vital bagi keberhasilan sekolah, terutama guru yang melaksanakan fungsi mengajarnya dengan penuh makna, maka sudah selayaknya ia perlu dibekali berbagai piranti dalam mengoptimalkan pemanfaatan teknologi informasi. Berbagai hasil penelitian mengungkapkan masih banyak guru yang gagap teknologi. Hal ini tergambar dari respon guru-guru yang merasa kurang pede dalam penggunaan dan pemanfaatan teknologi dalam proses pembelajaran maupun dalam kehidupan sosialnya, sebagimana diungkapkan oleh Prof. Fathur Rokhman dari UNNES bahwa 60\% guru belum familiar dengan komputer padahal hampir semua kegiatan saat ini tidak bisa lepas dari komputer termasuk di bidang pendidikan. Jika kondisi guru yang sebagian besar masih belum terampil dalam pemanfaatan teknologi agaknya perlu dicarikan penyebab dan solusi yang saling terkait antar berbagai unsur yakni; 1) sarana/prasarana, 2) kebijakan pimpinan sekolah dan pimpinan lembaga terkait, 3) kemampuan dan kecakapan dalam pemanfaatan teknologi informasi, 4) pendidikan dan pelatihan, 5) kendala yang dialami guru dalam pemanfaatan teknologi informasi.

Dalam pemanfaatan teknologi informasi selain sumber daya guru, diperlukan peran pimpinan atau kepala madrasah. Pimpinan yang tidak adaptif dengan perkembangan teknologi terkadang melahirkan kebijakan yang justru menjadikan guru itu sendiri menjadi gagap teknologi. Diperlukan langkah konkrit dan komitmen kepala madrasah terhadap kemajuan sekolah terkait dengan pemberdayaan guru dalam memanfaatkan teknologi informasi dalam pembelajaran. Persoalan itu perlu penyelesaian segera sehubungan beberapa kenyataan penguasaan teknologi informasi oleh guru madrasah relatif sangat rendah dan tidak merata (Sanusi, 2008).

Berbagai ulasan telah mendeskripsikan manfaat teknologi informasi dan komunikasi dalam proses pendidikan. Hanya saja persoalannya bagaimanakah kemampuan guru madrasah dalam upaya memanfaatkan potensi itu. Karena tak dapat disangkal lagi bahwa penguasaan teknologi informasi menjadi bagian dari tuntutan kompetensi guru, baik guna mendukung pelaksanaan tugasnya (penyusunan perencanaan, penyajian pembelajaran, evaluasi dan analisis hasil evaluasi) maupun sebagai sarana untuk mencari dan mengunduh sumber-sumber belajar.

Kehadiran teknologi informasi saat ini tidak mungkin dihindarkan, oleh karena itu diperlukan kesiapan untuk menerima teknologi informasi dan kemampuan untuk memanfaatkannya seoptimal mungkin. Untuk dapat memanfaatkan teknologi informasi dalam pembelajaran secara optimal, maka diperlukan hal-hal ; 1) visi pmebelajaran, 
2) relokasi sumber daya, 3) strategi implementasi, 4) akses siswa kepada teknologi informasi, 5) infrastruktur, 6) kesiapan tenaga pengajar, 7) kendali mutu, 8) kolaborasi dan konsorsiumpembelajaran berbasis teknologi informasi.

\section{SIMPULAN}

Era globalisasi dengan berbagai kecenderungannya telah melahirkan berbagai paradigma baru dalam dunia pendidikan. Visi, missi, tujuan, kurikulum, proses belajar mengajar, pendidik, peserta didik, manajemen, sarana prasarana, kelembagaan pendidikan dan lainnya kini tengah mengalami perubahan besar.

Madrasah sebagai lembaga pendidikan Islam seharusnya dapat memberikan jawaban yang tepat atas berbagai tantangan tersebut. Untuk menjawab pertanyaan ini, pendidikan Islam membutuhkan sumber daya manusia yang handal, memiliki komitmen dan etos kerja yang tinggi, manajemen yang berbasis sistem dan infra-struktur yang kuat, sumber dana yang memadai, kemauan politik yang kuat, serta standar yang unggul.

Intinya, globalisasi madrasah menuntut kemampuan daya saing yang kuat dalam teknologi, manajemen dan sumber daya manusia. Untuk dapat melakukan tugas tersebut, madrasah harus terus berusaha meningkatkan dan mengembangkan diri. Hanya dengan usaha yang sungguh-sungguh dan terus menerus, madrasah sebagai lembaga pendidikan Islam akan dapat merubah tantangan menjadi peluang.

\section{DAFTAR PUSTAKA}

Earl, M. ., \& Feeny, D. F. (2000). Managing IT as A Strategic Resource. London: McGraw-Hill.

Indrajit, R. E. (2004). Arsitektur Sekolah Modern Indonesia. Jakarta: Presentasi Sajian.

Jonassen, D. ., Camlell, J. ., \& Davidson, M. . (1993). Learning with Media: Restructing School with Technology Research and Development.

Knapp, L. R., \& Glenn, A. D. (1996). Restructuring School with Technology. Massachussets: Ally \& Bacon.

Kozma, R, B. (1991). Learning with Media. Review of Educational Research, Summer.

Maksum. (2006). Madrasah: Sejarah dan Perkembangannya. Jakarta: Logos Mann.

Means, B., \& Olson, K. (1993). Supporting School Reform with Educational Technology. Atlanta, Georgia: AERA.

Purwanto. (2005). Jejak Langkah Perkembangan Teknologi Pendidikan di Indonesia. Jakarta: PustekkomDepdiknas.

Sanusi, A. (2008). Mengurai Benang Kusut, Mencari Jalan Keluar Strategik. Jurnal Manajemen Pendidikan PPS UNINUS.

Subhan, A. (2012). Lembaga Pendidikan Islam Indonesia Abad Ke-20. Jakarta: Kencana.

Tilaar, H. A. R. (2000). Membenahi Pendidikan Nasional. Jakarta: Rineka Cipta.

Yunus, M. (1996). Sejarah Pendidikan Islam di Indonesia. Jakarta: Hidakarya Agung. 